\begin{tabular}{|c|c|c|}
\hline & Int.J.Curr.Microbiol.App.Sci (2021) 10(08): $92-98$ & \\
\hline & $\begin{array}{l}\text { International Journal of Current Microbiology and Applied Sciences } \\
\text { ISSN: 2319-7706 Volume } 10 \text { Number } 08 \text { (2021) } \\
\text { Journal homepage: } \underline{\text { http://www.ijcmas.com }}\end{array}$ & 30 \\
\hline $\begin{array}{l}\text { EXCELLENT } \\
\text { PUBLISHERS }\end{array}$ & & munw.ijemas.com \\
\hline
\end{tabular}

Original Research Article

https://doi.org/10.20546/ijcmas.2021.1008.012

\title{
Productivity of Maize (Zea mays L.) as Influenced by Nutrient Omission in Inceptisols of Nagaland
}

\author{
Mary Lalfakzuali* and Y. K. Sharma \\ Department of Agricultural Chemistry and Soil Science, Nagaland University: SASRD, \\ Medziphema, Nagaland, India \\ *Corresponding author
}

\section{A B S T R A C T}

Keywords

Maize, nutrient omission, growth, yield attributes, yield, nutrient uptake

Article Info

Accepted:

12 July 2021

Available Online:

10 August 2021
A field experiment was conducted at the instructional farm, Department of Agricultural Chemistry and Soil Science, SASRD, Nagaland University, during the Kharif season of 2019 to study the productivity of maize (Zea mays L.) as influenced by nutrient omission in Inceptisols of Nagaland. The experiment was laid out in randomized block design with three replications and seven treatments. The growth, yield attributes and yield of maize were found to be superior in the treatment where all nutrients (N, P, K, Zn, B, lime) were applied. Maximum grain and stover yield (3975.03 and $5107.66 \mathrm{~kg} \mathrm{ha}^{-1}$, respectively) were recorded with treatment $T_{1}$ whereas the lowest was observed with omission of $\mathrm{N}$ (2996.91 and $3940.51 \mathrm{~kg} \mathrm{ha}^{-1}$, respectively).N, P, K, Zn, B and lime omission reduced grain yield to the extent of 24.6, 21.0, 13.6, 8.0, 9.1 and $17.4 \%$ respectively over $\mathrm{T}_{1}$ treatment. The per cent grain yield reduction based on limiting nutrients were found in the order $\mathrm{N}>\mathrm{P}>$ Lime $>\mathrm{K}>\mathrm{B}>\mathrm{Zn}$. The nutrient uptake by maize, available nitrogen, phosphorus, potassium, exchangeable calcium and magnesium, available zinc and boron in post-harvest soil were found significantly higher under the treatment $T_{1}$.

\section{Introduction}

Maize (Zea mays L.) belongs to family Poaceae, is one of the most important cereal crops in the agricultural economy of the world both as requirement for man and as feed for the animals. Kharif is the most important season which covers $80 \%$ of the total area of maize cultivation in India. In the Northeast India context, maize is the second most important crop of cereal after rice, which is mostly grown in the region of upland acidic soil conditions (Marwein et al., 2016).

Site specific nutrient management refers to the productive, field specific nutrient management system in a crop or cropping system with a view to optimize the demand and supply of nutrients according to their differences in cycling of nutrients through their soil-plant 
systems (Wang et al., 2007). Maize is a crop with wide spacing which have slow rate of growth in its early stage of crop cycle, leading to losses of water and nutrient through weed and evaporation, respectively. The key aspect of increasing production and productivity of maize relies on the application of plant nutrients in adequate and balanced quantities.

Nagaland has four types of soil based on their order i.e. Alfisols, Entisols, Inceptisols and Ultisols. Majority of the soils in this region falls under Inceptisols (66\%). Almost all the soils in Nagaland are deficient in nitrogen and phosphorus and medium to high in potassium, while other micronutrients like $\mathrm{Fe}, \mathrm{Mn}, \mathrm{Cu}, \mathrm{B}$ and Mo may be sufficient for low to medium level of crop production but may not be sufficient for high level of crop production. Proper and timely nutrition of crop in a correct amount and proper ratios and adequate supply of all essential nutrients based on crop needs is the solution in order to achieve high crop yields.

\section{Materials and Methods}

A field experiment was conducted at the instructional farm, Department of Agricultural Chemistry and Soil Science, SASRD, Nagaland University, during the Kharif season of 2019 to study the productivity of maize (Zea mays L.) as influenced by nutrient omission in Inceptisols of Nagaland. The experiment was laid out in randomized block design (RBD) with three replications and seven treatments viz. $\mathrm{T}_{1}$ (All- $\mathrm{N}, \mathrm{P}, \mathrm{K}, \mathrm{Zn}, \mathrm{B}$, Lime), $\mathrm{T}_{2}$ (All-N), $\mathrm{T}_{3}$ (All-P), $\mathrm{T}_{4}$ (All-K), $\mathrm{T}_{5}$ (All-Zn), $\mathrm{T}_{6}$ (All-B) and $\mathrm{T}_{7}$ (All-Lime). The soil of the experimental farm was categorized as sandy clay loam. The recommended dose of fertilizer was 120: 60: 60: 10: 0.5: $300 \mathrm{~N}$ : P: $\mathrm{K}$ : Zn: B: Lime $\mathrm{kg} \mathrm{ha}^{-1}$ respectively. Half dose of nitrogen and full dose of phosphorus, potassium, zinc and boron were applied at sowing time as basal application. Remaining dose of nitrogen was applied in two splits i.e. half at 30 DAS and the remaining half at 60 DAS as top dressing. Lime $\left(\mathrm{CaCO}_{3}\right)$ was applied 5 days before sowing as basal. Seeds were sown on $17^{\text {th }}$ of June, 2019.From each plot five plants were selected randomly and plant growth parameters were recorded at regular interval. Yield attributes were recorded at the time of harvest.

Nitrogen content was estimated by alkaline potassium permanganate method (Subbiah and Asija, 1956), phosphorus and potassium content by Bray's No.1 method (Brays and Kurtz, 1945) and flame photometer methods (Hanway and Heidal, 1952), respectively.

Exchangeable calcium and magnesium was determined by Versenate method (Cheng and Bray, 1951), zinc content was extracted by DTPA extractable micronutrients method (Lindsay and Norvell, 1978) and boron content was extracted by Azomethine-H colorimetric method (Berger and Truog, 1939).

\section{Results and Discussion}

\section{Growth and yield attributes of maize}

The plant height $(\mathrm{cm})$ at 30 DAS was not significantly influenced by the omission of nutrients. However at 60 and 90 DAS, significant difference in the plant height was observed. The maximum height of the plant was observed in $\mathrm{T}_{1}$ which received all nutrients $(227.07 \mathrm{~cm})$ followed by $\mathrm{T}_{4}(219.41$ $\mathrm{cm}$ ) with omission of $\mathrm{K}$, meanwhile the minimum plant height was observed in $\mathrm{N}$ omitted plot $\mathrm{T}_{2}(202.62 \mathrm{~cm})$. It was observed that the most limiting nutrient for the growth of maize crop was $\mathrm{N}$ followed by lime and phosphorus (Sahu et al., 2017; Sushma and Sao, 2018).

The yield attributes parameters such as number of cobs plant ${ }^{-1}$ was not found to be significantly influenced by omission of 
nutrients, while the cob length and number of grains $\mathrm{cob}^{-1}$ showed significant variation among the various treatments.

The cob length of maize was found to be significantly highest $(20.10 \mathrm{~cm})$ with $\mathrm{T}_{1}$ which received all nutrients and lowest $(16.30 \mathrm{~cm})$ with omission of $\mathrm{N}$ treatment $\left(\mathrm{T}_{2}\right)$. Similarly, $\mathrm{T}_{1}$ (447.83) recorded highest and $\mathrm{T}_{2}$ (370.23) recorded lowest number of grains $\mathrm{cob}^{-1}$.

\section{Yield of maize}

The grain and stover yield of maize varied from 2996.91 to $3975.03 \mathrm{~kg} \mathrm{ha}^{-1}$ and 3940.51 to $5107.66 \mathrm{~kg} \mathrm{ha}^{-1}$ respectively, irrespective of the treatments. The highest grain yield was recorded in $\mathrm{T}_{1}$ with all the nutrients provided (3975.03 $\mathrm{kg} \mathrm{ha}^{-1}$ ) followed by $\mathrm{T}_{5}$ with omission of $\mathrm{Zn}\left(3656.83 \mathrm{~kg} \mathrm{ha}^{-1}\right)$ which was at par with $\mathrm{T}_{6}$ with omission of $\mathrm{B}(3612.25 \mathrm{~kg}$ $\mathrm{ha}^{-1}$ ). The lowest grain yield was found in $\mathrm{T}_{2}$ with omission on $\mathrm{N}\left(2996.91 \mathrm{~kg} \mathrm{ha}^{-1}\right)$. It was observed that $\mathrm{N}, \mathrm{P}, \mathrm{K}, \mathrm{Zn}, \mathrm{B}$ and lime omission reduced grain yield to the extent of 24.6, 21.0, 13.6, 8.0, 9.1 and $17.4 \%$ respectively over $\mathrm{T}_{1}$ treatment (Mishra et al., 2007). The highest stover yield was recorded in $\mathrm{T}_{1}$ which received all nutrients $(5107.66 \mathrm{~kg}$ $\mathrm{ha}^{-1}$ ) followed by $\mathrm{T}_{6}$ with omission of $\mathrm{B}$ $\left(4768.82 \mathrm{~kg} \mathrm{ha}^{-1}\right)$ which was statistically at par with $\mathrm{T}_{5}$ with omission of $\mathrm{Zn}\left(4730.60 \mathrm{~kg} \mathrm{ha}^{-1}\right)$. The lowest stover yield was recorded in $\mathrm{T}_{2}$ with omission of $\mathrm{N}\left(3940.51 \mathrm{~kg} \mathrm{ha}^{-1}\right)$.

Table.1 Initial soil properties of the experimental field

\begin{tabular}{|c|c|c|}
\hline Soil parameters & Value & Methods employed \\
\hline $\mathrm{pH}$ & 4.9 & Digital pH meter (Jackson, 1973) \\
\hline $\begin{array}{l}\text { Organic carbon } \\
\left(\mathrm{g} \mathrm{kg}^{-1}\right)\end{array}$ & 12.8 & $\begin{array}{l}\text { Walkley and Black method (Jackson, } \\
\text { 1973) }\end{array}$ \\
\hline $\begin{array}{l}\text { Available N } \\
\left(\mathrm{kg} \mathrm{ha}^{-1}\right)\end{array}$ & 220.8 & $\begin{array}{l}\text { Alkaline potassium permanganate } \\
\text { method (Subbiah and Asija, 1956) }\end{array}$ \\
\hline $\begin{array}{l}\text { Available P } \\
\left(\mathbf{k g ~ h a}^{-1}\right)\end{array}$ & 25.6 & $\begin{array}{l}\text { Bray's No.1 method (Bray and Kurtz, } \\
\text { 1945) }\end{array}$ \\
\hline $\begin{array}{l}\text { Available K } \\
\left(\text { kg ha }^{-1}\right)\end{array}$ & 128.3 & $\begin{array}{l}\text { Flame Photometer (Hanway and Heidal, } \\
\text { 1952) }\end{array}$ \\
\hline $\begin{array}{l}\text { Exchangeable Ca } \\
\quad\left(\mathrm{cmol} \mathrm{kg}^{-1}\right)\end{array}$ & 1.2 & $\begin{array}{l}\text { Versenate Method (Cheng and Bray, } \\
\text { 1951) }\end{array}$ \\
\hline $\begin{array}{l}\text { Exchangeable Mg } \\
\left(\mathrm{cmol} \mathrm{kg}^{-1}\right)\end{array}$ & 0.61 & $\begin{array}{l}\text { Versenate Method (Cheng and Bray, } \\
\text { 1951) }\end{array}$ \\
\hline $\begin{array}{l}\text { Available Zn } \\
\left(\mathrm{mg} \mathrm{kg}^{-1}\right)\end{array}$ & 0.68 & $\begin{array}{l}\text { DPTA extractable micronutrients method } \\
\text { (Lindsay and Norvell, 1978) }\end{array}$ \\
\hline $\begin{array}{l}\text { Available B } \\
\left(\mathrm{mg} \mathrm{kg}^{-1}\right)\end{array}$ & 0.33 & Azomethine-H method (Gupta, 1967) \\
\hline $\begin{array}{l}\text { Total potential acidity } \\
\left(\mathbf{c m o l ~ k g}^{-1}\right)\end{array}$ & $11.89^{\circ}$ & $\begin{array}{l}\mathrm{BaCl}_{3}-\text { Triethanolamine extract method } \\
\text { (Baruah and Barthakur, 1999) }\end{array}$ \\
\hline $\begin{array}{l}\text { Particle size distribution (\%) } \\
\text { i) Sand } \\
\text { ii) Silt } \\
\text { iii) Clay }\end{array}$ & $\begin{array}{l}49.5 \\
26.2 \\
24.3\end{array}$ & $\begin{array}{c}\text { International pipette method } \\
\text { (Piper, 1966) }\end{array}$ \\
\hline Textural Class & & Sandy Clay Loam \\
\hline
\end{tabular}


Table.2 Effect of nutrient omission on growth, yield attributes and yield of maize

\begin{tabular}{|c|c|c|c|c|c|c|c|c|}
\hline \multirow[t]{2}{*}{ Treatments } & \multicolumn{3}{|c|}{ Plant height (cm) } & \multirow{2}{*}{$\begin{array}{l}\text { No. of cobs } \\
\text { plant }^{-1}\end{array}$} & \multirow{2}{*}{$\begin{array}{l}\text { Cob length } \\
\quad(\mathrm{cm})\end{array}$} & \multirow{2}{*}{$\begin{array}{l}\text { No. of grains } \\
\text { cob }^{-1}\end{array}$} & \multicolumn{2}{|c|}{ Yield (kg ha $\left.{ }^{-1}\right)$} \\
\hline & 30 DAS & 60 DAS & 90 DAS & & & & Grain & Stover \\
\hline $\mathbf{T}_{1}:$ All & 73.80 & 202.57 & 227.07 & 1.33 & 20.10 & 447.83 & 3975.03 & 5107.66 \\
\hline $\mathbf{T}_{2}:$ All-N & 66.67 & 174.50 & 202.62 & 1.00 & 16.30 & 370.23 & 2996.91 & 3940.51 \\
\hline$T_{3}:$ All-P & 66.27 & 183.47 & 212.50 & 1.00 & 17.17 & 382.47 & 3140.06 & 4160.28 \\
\hline$T_{4}:$ All-K & 71.30 & 188.70 & 219.41 & 1.33 & 18.90 & 409.67 & 3435.15 & 4482.60 \\
\hline $\mathbf{T}_{5}:$ All-Zn & 69.30 & 185.50 & 216.71 & 1.00 & 18.17 & 397.43 & 3656.83 & 4730.60 \\
\hline$T_{6}:$ All-B & 72.63 & 184.03 & 217.53 & 1.00 & 18.37 & 402.27 & 3612.25 & 4768.82 \\
\hline $\mathbf{T}_{7}:$ All-Lime & 69.23 & 183.13 & 211.53 & 1.00 & 17.67 & 392.70 & 3283.86 & 4210.45 \\
\hline SEm \pm & 3.98 & 2.31 & 2.49 & 0.16 & 0.61 & 9.62 & 33.00 & 56.35 \\
\hline $\mathrm{CD}(\mathrm{p}=0.05)$ & NS & 7.11 & 7.66 & NS & 1.88 & 29.64 & 101.69 & 173.62 \\
\hline
\end{tabular}

Note: $\mathrm{NS}=$ Non-significant at $5 \%$ level of significance

Table.3 Effect of nutrient omission on macro and micro nutrients uptake by maize under Inceptisol of Nagaland

\begin{tabular}{|c|c|c|c|c|c|c|c|}
\hline & \multicolumn{5}{|c|}{ Nutrient uptake $\left(\mathrm{kg} \mathrm{ha}^{-1}\right)$} & \multicolumn{2}{|c|}{ Nutrient uptake $\left(\mathrm{g} \mathrm{ha}^{-1}\right)$} \\
\hline & $\mathbf{N}$ & $\mathbf{P}$ & $\mathbf{K}$ & Ca & Mg & Zn & B \\
\hline $\mathrm{T}_{1}:$ All & 122.32 & 44.26 & 104.59 & 18.71 & 14.53 & 54.55 & 59.29 \\
\hline $\mathbf{T}_{2}:$ All-N & 54.38 & 25.04 & 67.30 & 12.97 & 9.60 & 40.59 & 44.45 \\
\hline $\mathbf{T}_{3}:$ All-P & 73.30 & 16.34 & 70.86 & 12.64 & 9.35 & 42.66 & 46.57 \\
\hline $\mathbf{T}_{4}:$ All-K & 98.10 & 35.46 & 58.87 & 15.07 & 11.56 & 46.82 & 51.00 \\
\hline $\mathbf{T}_{5}:$ All-Zn & 98.41 & 32.20 & 83.88 & 15.59 & 10.72 & 41.44 & 54.31 \\
\hline $\mathrm{T}_{6}:$ All-B & 101.14 & 35.73 & 87.12 & 14.72 & 11.18 & 49.07 & 43.96 \\
\hline $\mathbf{T}_{7}:$ All-Lime & 73.24 & 23.57 & 73.44 & 9.87 & 8.06 & 44.40 & 48.26 \\
\hline SEm \pm & 1.13 & 0.59 & 1.01 & 0.48 & 0.31 & 0.34 & 0.38 \\
\hline $\mathrm{CD}(\mathrm{p}=\mathbf{0 . 0 5})$ & 3.50 & 1.83 & 3.11 & 1.47 & 0.97 & 1.05 & 1.17 \\
\hline
\end{tabular}


Fig.1 Effect of nutrient omission on macro nutrients uptake by maize under Inceptisol of Nagaland

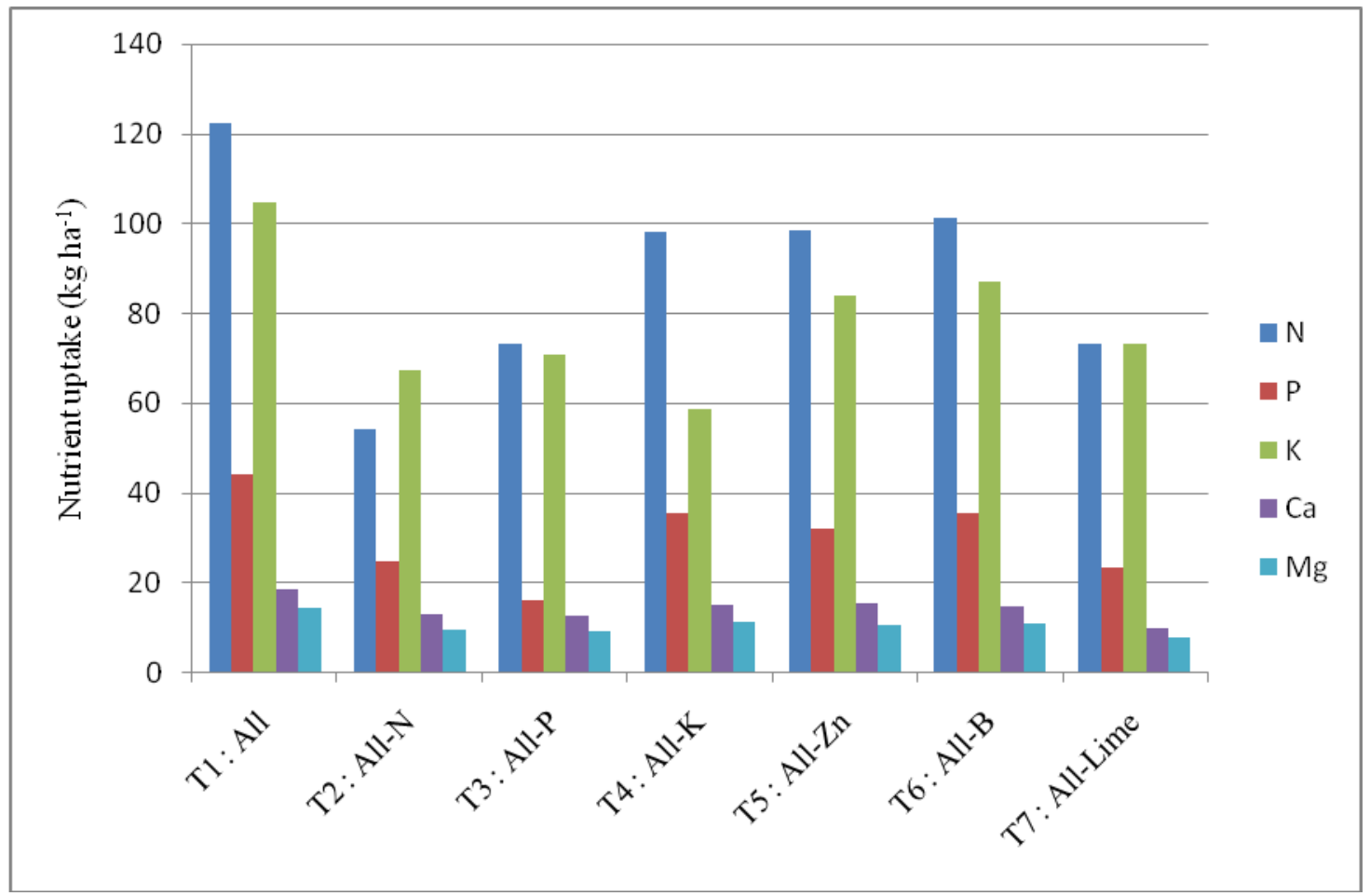

Fig.2 Effect of nutrient omission on micro nutrients uptake by maize under Inceptisol of Nagaland

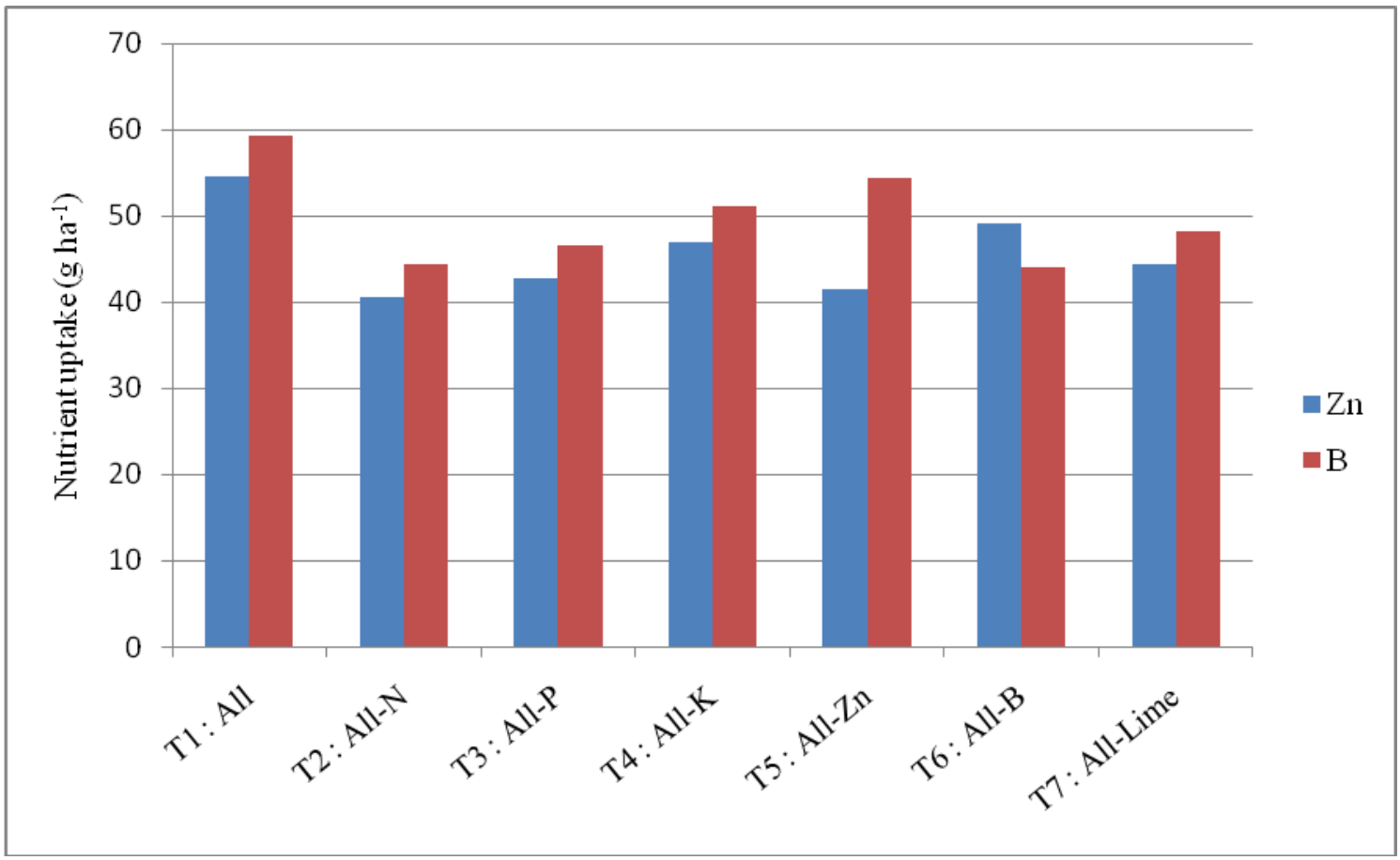


Maximum reduction (22.8\%) in stover yield was observed with nitrogen omission while minimum reduction $(6.6 \%)$ was recorded when boron was omitted from treatments. This was in conformity with Singh et al., (2018). The reductions in grain and stover yield were high with the omission of $\mathrm{N}$ and $\mathrm{P}$. $\mathrm{N}$ was the most critical nutrient for optimum grain yield of the crop. The yield was significantly high where all the nutrients ( $\mathrm{N}, \mathrm{P}, \mathrm{K}, \mathrm{Zn}, \mathrm{B}$, Lime) were incorporated.

\section{Nutrient uptake}

Nitrogen uptake was highest in treatment $T_{1}$ (122.32 $\mathrm{kg} \mathrm{ha}^{-1}$ ) where all nutrients were applied and lowest was observed in nitrogen omitted plot $\mathrm{T}_{2}\left(30.47 \mathrm{~kg} \mathrm{ha}^{-1}\right)$. Total nitrogen uptake was reduced by 55.5, 40.1, 19.8, 19.5, 17.3 and $40.1 \%$ due to omission of $\mathrm{N}, \mathrm{P}, \mathrm{K}$, $\mathrm{Zn}, \mathrm{B}$ and lime, respectively over $\mathrm{T}_{1}$ treatment.These results are in line with those of Mishra et al., (2007). All nutrients treatment $\mathrm{T}_{1}\left(44.26 \mathrm{~kg} \mathrm{ha}^{-1}\right)$ recorded the highest $\mathrm{P}$ uptake and maximum reduction was noted with omission of $\mathrm{P}\left(16.34 \mathrm{~kg} \mathrm{ha}^{-1}\right)$ followed by lime and N.It was observed that omission of N, P, K, Zn, B and lime reduced total phosphorus uptake by maize to the extent of $43.4,63.1,19.8,27.2,19.3$ and $46.7 \%$ respectively over $\mathrm{T}_{1}$ (Singh, 2018). Maximum reduction $(43.7 \%)$ in total potassium was recorded with $\mathrm{K}$ omission $\left(58.87 \mathrm{~kg} \mathrm{ha}^{-1}\right.$ ) followed by omission of $\mathrm{N}(35.6 \%)$ and $\mathrm{P}$ $(32.2 \%)$. The highest $\mathrm{K}$ uptake was recorded in $\mathrm{T}_{1}\left(104.59 \mathrm{~kg} \mathrm{ha}^{-1}\right)$.

Calcium uptake was significantly highest in $\mathrm{T}_{1}$ $\left(18.71 \mathrm{~kg} \mathrm{ha}^{-1}\right)$ and the lowest Ca uptake was observed in $\mathrm{T}_{7}\left(9.87 \mathrm{~kg} \mathrm{ha}^{-1}\right)$. Omission of $\mathrm{N}$, $\mathrm{P}, \mathrm{K}, \mathrm{Zn}, \mathrm{B}$ and lime reduced total Ca uptake by $30.9,32.4,19.4,16.7,21.3$ and $47.2 \%$, respectively over $\mathrm{T}_{1} \cdot \mathrm{T}_{1}\left(14.53 \mathrm{~kg} \mathrm{ha}^{-1}\right)$ where all nutrients were applied recorded the highest $\mathrm{Mg}$ uptake while lime omitted $\mathrm{T}_{7}\left(8.06 \mathrm{~kg} \mathrm{ha}^{-}\right.$ ${ }^{1}$ ) recorded the lowest.Omission of $\mathrm{N}, \mathrm{P}, \mathrm{K}$,
$\mathrm{Zn}, \mathrm{B}$ and lime decreased the total magnesium uptake by 33.9, 35.6, 20.4, 26.2, 23.0 and $44.5 \%$, respectively over $\mathrm{T}_{1}$. The zinc uptake was significantly superior in all nutrients treatment $\mathrm{T}_{1}\left(54.55 \mathrm{~g} \mathrm{ha}^{-1}\right)$ over all other treatments, while the lowest was recorded in $\mathrm{N}$ omitted treatment $\mathrm{T}_{2}\left(40.59 \mathrm{~g} \mathrm{ha}^{-1}\right)$. Total zinc uptake was reduced by $25.6,21.8,14.2,24.0$, 10.0 and $18.6 \%$ with omission of $\mathrm{N}, \mathrm{P}, \mathrm{K}, \mathrm{Zn}$, $\mathrm{B}$ and lime, respectively over $\mathrm{T}_{1} . \mathrm{T}_{1}$ recorded the highest boron uptake (59.29 $\left.\mathrm{g} \mathrm{ha}^{-1}\right)$ and $\mathrm{B}$ omitted treatment $\mathrm{T}_{2}\left(43.96 \mathrm{~g} \mathrm{ha}^{-1}\right)$ recorded the lowest. Omission of N, P, K, Zn, B and lime reduced total boron uptake by $25.0,21.4$, $14.0,8.0,25.8$ and $18.6 \%$, respectively over $\mathrm{T}_{1}$ treatment.

Based on the above findings, it may be concluded that application of $\mathrm{N}, \mathrm{P}, \mathrm{K}, \mathrm{Zn}, \mathrm{B}$ and lime $\left(120,60,60,10,0.5,300 \mathrm{~kg} \mathrm{ha}^{-1}\right.$, respectively) might be beneficial for achieving higher productivity of maize under Inceptisols of Nagaland. The most limiting nutrient for the growth and yield of maize was nitrogen followed by phosphorus and lime.

\section{References}

Berger, K. C. and Truog, E. 1939. Boron determination in soil and plants. Industrial and Engineering Chemistry Analytical Edition. 11: 540-545.

Bray, R. H. and Kurtz, L. T. 1945. Determination of total, organic and available forms of phosphorus in the soil. Soil Science. 59: 39-45.

Cheng, K. L. and Bray, R. H. 1951. Determination of calcium and magnesium in soil and plant material. Soil Science. 72 (6): 449-458.

Hanway, J. and Heidal, H. S. 1952. Soil Testing Laboratory Procedures. Jowa Agriculture. 57:1-31.

Lindsay, W. L. and Norvell, W. A. 1978. Development of a DTPA (Diethylene triamine penta acetic acid) soil test for 
zinc, iron, manganese and copper. Soil Science Society of America Journal. 42: 421-428.

Marwein, M. A., Choudhury, B. U., Chakraborty, D., Kumar, M., Das, A. and Rajkhowa, D. J. 2016. Response of water deficit regime and soil amelioration on evapotranspiration loss and water use efficiency of maize (Zea mays L.) in subtropical Northeastern Himalayas. International Journal of Biometeorology. 61 (5): 845-855.

Mishra, V. N., Patil, S. K., Das, R. O., Shrivastava, L. K., Samadhiya, V. K. and Sengar, S. S. 2007. Site-specific nutrient management for maximum yield of rice in Vertisol and Inceptisol of Chhattisgarh. Paper presented in South Asian Conference on "Water in Agriculture: management options for increasing crop productivity per drop of water", during November, 15-17, held at IGKV, Raipur C.G., India. p.136.

Sahu, N., Mishra, V. N., Shrivastava, L. K. and Jatav, G. 2017. Crop response based assessment of limiting nutrients using site specific nutrient management for yield maximization in Vertisols of Bemetara District of Chhattisgarh, India. International Journal of Current Microbiology and
Applied Sciences. 6 (6): 1784-1791.

Singh, S. P., Parmanand, Choudhary, M., Patel, C. R., Paikra, K. K. and Sharma, Y. K. 2018. Assessment of nutrient deficiencies in rice (Oryza sativa) through nutrient omission in Vertisol and Inceptisol of Chhattisgarh. International Journal of Current Microbiology and Applied Sciences. 7(7): 3525-3533.

Singh, V. 2018. Breaking yield barrier in wheat (Triticum aestivum) through site specific nutrient management..Annals of Plant and Soil Research. 20 (1): 1215.

Subbiah, B. V. and Asija, G. L. 1956. Rapid procedure for the estimation of available nitrogen in the soils. Current Science. 25: 259-260.

Sushma and Sao, Y. 2018. Site-specific nutrient management use in two soil type Vertisol and Inceptisol of Mungeli district of Chhattisgarh on grain and straw yield. Journal of Pharmacognosy and Phytochemistry. 7 (6): 387-388.

Wang, Guanghuo, Zhang, Q. C., Witt, C. and Buresh, R. J. 2007. Opportunities for yield increase and environmental benefits through site-specific Nutrient Management in rice system of Zhejiang province China. Agricultural Systems. 94 (3): 801-806.

\section{How to cite this article:}

Mary Lalfakzuali and Sharma, Y. K. 2021. Productivity of Maize (Zea mays L.) as Influenced by Nutrient Omission in Inceptisols of Nagaland. Int.J.Curr.Microbiol.App.Sci. 10(08): 92-98. doi: https://doi.org/10.20546/ijcmas.2021.1008.012 